\title{
Workplace conditions created by principals for their teachers' professional development in Vietnam
}

Hai-Ngoc Tran, Duc-Chinh Nguyen, Gia-Viet Nguyen, Thi-Nga Ho, Quynh-Tho Thi Bui \& Ngoc-Ha Hoang

To cite this article: Hai-Ngoc Tran, Duc-Chinh Nguyen, Gia-Viet Nguyen, Thi-Nga Ho, Quynh-Tho Thi Bui \& Ngoc-Ha Hoang (2020): Workplace conditions created by principals for their teachers' professional development in Vietnam, International Journal of Leadership in Education, DOI: 10.1080/13603124.2019.1708472

To link to this article: https://doi.org/10.1080/13603124.2019.1708472

\section{曲 Published online: 05 Jan 2020.}

Submit your article to this journal $\pi$

Q View related articles $\sqsubset$

View Crossmark data $־$ 


\title{
Workplace conditions created by principals for their teachers' professional development in Vietnam
}

\author{
Hai-Ngoc Tran (iD), a , Duc-Chinh Nguyen (iD)', Gia-Viet Nguyen ${ }^{\text {d,e }}$, Thi-Nga Hof, Quynh- \\ Tho Thi Buig and Ngoc-Ha Hoang ${ }^{\text {h }}$
}

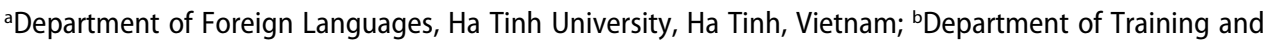
Research, Vietnam National Institute of Educational Sciences, Ha Noi, Vietnam; 'Department of English, Da Nang College of Foreign Language Studies, Da Nang, Vietnam; dSchool of Albert Enstein, Ha Tinh, Vietnam; eDepartment of Foreign Languages, Ha Tinh University, Ha Tinh, Vietnam; fDepartment of External Relations

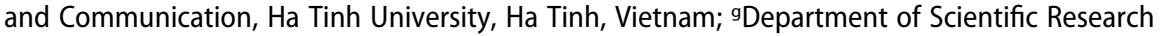

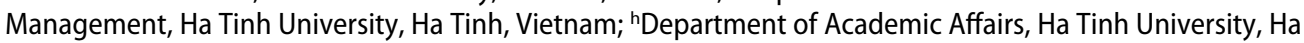
Tinh, Vietnam

\begin{abstract}
Teacher professional development (TPD) plays a significant role in better school improvement and student achievements. Research on TPD shows that favorable workplace conditions greatly enhance teachers' teaching knowledge and practice. This research was conducted to find out what workplace conditions principals had created to promote TPD in four schools in a province in Vietnam. The study utilizes multiple-site case study design relating to principal leadership and TPD in those schools. The four key workplace conditions were identified in this study including collaboration, teacher empowerment, supervision and evaluation, and teachers' motivational strategies. Based on the findings, the study offers implications for both research and practice on principal leadership for TPD within and beyond the Vietnamese context.
\end{abstract}

\section{Introduction}

One of the key conclusions drawn from the sustainable education reform studies over the last two decades is the vital significance of teacher professional development (TPD) (Clement \& Vandenberghe, 2001; Darling-Hammond \& Richardson, 2009; Qian, Walker, \& Yang, 2017; Timperley, 2011; Vescio, Ross, \& Adams, 2008). The first formal studies on TPD focused mainly on the roles of pre-service education and in-service workshops/seminars in TPD (Joyce, 1988). However, TPD has been a process initiated during pre-service teacher education time and continues through job-embedded, collaborative, coherent and reflective professional activities, for the last few decades (Hallinger, Piyaman, \& Viseshsiri, 2017; Kwakman, 2003; Lieberman \& Pointer Mace, 2008; Opfer \& Pedder, 2011; Poekert, 2012; Timperley, 2011; Webster-Wright, 2009). This led researchers' attention to understanding how workplace conditions enhance teachers' participation in productive and effective learning during their teaching careers 
(Geijsel, Sleegers, Stoel, \& Krüger, 2009; He \& Ho, 2017; Qian et al., 2017; Sleegers, Thoonen, Oort, \& Peetsma, 2014; Youngs \& King, 2002). A central theme in these studies as well as in the research literature is the role of school leaders in creating favorable working conditions for TPD.

Recent studies on TPD have paid more attention to developing countries where the quality and scope of pre-service teacher education need to be reformed in response to educational changes (Hairon \& Dimmock, 2012; Hallinger \& Truong, 2016; Hallinger et al., 2017; Lai, Li, \& Gong, 2016; Qian et al., 2016; Somprach, Tang, \& Popoonsak, 2016; Wang, 2016). In Vietnam, the Communist Party and the government have recognized that the success of education reforms depends mainly on the ability of principals and teachers to learn new and innovative knowledge, skills and attitudes on-the-job (The Communist Party of Vietnam [CPV], 2012; London, 2010; Mai, 2007; Mau, 1998; Ministry of Education and Training [MOET], 2012; Nguyen 2003, 2012; Tran, Hallinger, \& Truong, 2018). In order to find out the impacts of principal leadership on their TPD, this research specifically addressed the following question, 'What workplace conditions do the principals in four schools in Hong Lam province create to promote their teachers' professional development?'. By addressing this question, our aim is to explore whether the principals used practices highlighted or suggested by the literature have impact on TPD.

This study used a qualitative case study of leadership and TPD in four schools. Our analysis aimed at identifying the favorable working conditions for teachers created by their principals to promte TPD in their schools in Hong Lam province, Vietnam. In this way, the study highlights the cultural dimensions of principal support, which are specific to the educational and sociocultural context of Vietnam. This approach is congruent with Bajund's advocacy for cultural aspects of leadership unique to each specific education system.

\section{Vietnamese context and literature review}

We believe that it would be impossible to understand how principals promote TPD in the society of Vietnam without taking the influences of the social, economic, educational and cultural context into consideration. In this section, cultural and educational context of Vietnam will be discussed. Then, we will discuss the roles of principals in creating favorable conditions for teachers' professional learning.

\section{Social and cultural context of Vietnam}

The Vietnamese culture has been influenced by a blend of different indigenous ethnic groups, Chinese Confucianism and Taoism, Buddhism, Communism, and Western cultures including French and American ones (Borton, 2000; Dalton, Hac, Nghi, \& Ong, 2001; Nguyen, 2013, 2016; Vasavakul, 2019). For example, although social relationships among Vietnamese are strongly hierarchical and collectivist as a result of Confucianism influence (Borton, 2000; Duiker, 1995; Jamieson, 1993; Hallinger \& Truong, 2016; Nguyen, 2013), Communism has reshaped these traditional Confucian and Taoism values into a unique Vietnamese form (Borton, 2000; Dalton et al., 2001; Nguyen, 2016). Moreover, since Vietnam started its open-door policy and integrated into the world in 1986, Vietnamese culture has been also influenced more by Western values 
such as individualism and equality in social relations (Dalton et al., 2001; Nguyen, 2016; Vasavakul, 2019).

However, hierarchy continues to be a normative feature of social relations in Vietnamese society. Elders or seniors expect respect from younger people or those recognized as having lower social rank or social status (Dalton et al., 2001; Lan, 2002; Vasavakul, 2019). Respect is expressed in several forms such as listening attentively to, or not disobeying your seniors' advice and suggestions, or in the ways we address one another in communication. An obvious indication of respect involves addressing one another in communication by using various pronouns. Such pronouns reflect the order, age and status of addressers and addressees in the family, community, or society (Truong \& Hallinger, 2017; Vasavakul, 2019). In schools, juniors whether students, teachers or principals typically wait for seniors to express their opinion first in order to avoid causing conflict or loss of face (Borton, 2000; Dalton et al., 2001; Hallinger \& Truong, 2014; Jamieson, 1993; Tran et al., 2018; Truong \& Hallinger, 2017; Truong, Hallinger, \& Sanga, 2016; Vasavakul, 2019).

These values and norms are evident in the education system. Vietnamese teachers have been considered among the most important people not only in education but also in wider society (Hoang, 2002; Huynh, 2002; Hallinger \& Truong, 2014; Lan, 2002). Due to the influence of Confucianism, 'the teacher occupies a central place in the student's life and is revered for the wisdom he provides' (Ozmon \& Craver, 2008, p. 117). Thus, the role of both teachers and principals must be interpreted in light of the context of culture and education in Vietnam (Huynh, 2002; Truong \& Hallinger, 2017).

\section{Education in Vietnam}

Vietnam has carried out the doi moi (reform) policy since 1986 and has focused on the socio-economic development of Vietnam (Duggan, 2001; Hac, 1998; MOET, 2012; Nguyen, 2002). Education is always considered to play a vital part in the doi moi process, the current education system is, nevertheless, ill-equipped regarding the quality of curriculum, facilities, teaching methods and teaching staff (Duc, 2008; London, 2011; Nguyen, 2002; Tran et al., 2018; Truong \& Hallinger, 2017). Addressing these challenges has been the goal of educational reforms since the beginning of the millennium (Duc, 2008; London, 2011).

In Vietnam, the MOET is responsible for organizing the functional responsibilities for education including curriculum, teacher qualifications, educational standards and testing. However, it is noted that in Vietnam, authority over many of these issues is shared with the Communist Party committees at the national, provincial, district and school levels (Hallinger \& Truong, 2016; Tran et al., 2018). This shared authority division, both at the educational system and school levels, reinforces the multiple purposes of education in Vietnam: political/moral qualities $(d u c)$ and professional knowledge (tai) (Doan, 2005; London, 2011). Duc refers to virtues or moral qualities and incorporates values that arise from Confucianism, Taoism and Communism. Duc can, for example, refer to traditional cultural values such as filial piety (hieu), loyalty, respect for 'seniors' as well as to faithfulness to the values of the Communist Party (Dalton et al., 2001; Hallinger \& Truong, 2016; Hoang, 2002; Huynh, 2002; Nguyen, 2002; Truong et al., 2016). A big distribution of the formal school curriculum in schools in Vietnam is allocated to 
political and moral education (Doan, 2005; Vasavakul, 2019). Tai refers to knowledge, skills, professional competence or ability (Mai, 2007; Vasavakul, 2019). When a Vietnamese refers to a 'tai teacher', it implies that the teacher masters profound professional knowledge and skillful teaching methods (Hamano, 2008; Mau, 1998; Nguyen, 2002; Tran et al., 2018).

\section{Principal leadership and teacher professional development}

The school principal has been believed to play a significant role in organizing and supporting their teachers' professional development (Clement \& Vandenberghe, 2001; Cravens, 2008; Fullan, 2001; Hallinger \& Liu, 2016; Leithwood, 1992; Newmann, Youngs, \& King, 2000; Sleegers et al., 2014). The development of a 'professional learning community' (Harris, Jones, \& Huffman, 2017; Vescio et al., 2008; Wang, 2016) or a 'learning culture' (Qian et al., 2016; Thoonen, Sleegers, Oort, \& Peetsma, 2012) requires effective leadership both from the principal and middle-level leaders (Clement \& Vandenberghe, 2001; Geijsel et al., 2009; Leithwood, 1992; Leithwood \& Louis, 2011; Sleegers et al., 2014). Thus, researchers who have investigated how workplace conditions influence teachers' engagement in productive professional development have highly appreciated the important contributions of principal leadership regardless of the leadership styles principals exercise such as autocratic, transactional, transformational or instructional one (Geijsel et al., 2009; Hallinger \& Liu, 2016; He \& Ho, 2017; Sleegers et al., 2014; Somprach et al., 2016; Youngs \& King, 2002).

Robinson, Lloyd, and Rowe (2008) stated that the principal's constructive participation and effective support for TPD is the most significant factor by which school leadership has most influences on student learning, improvement and achievements. This important finding motivated more researchers to look for better understandings of how school principals create favorable conditions to promote the productive TPD in their schools (Geijsel et al., 2009; Hallinger \& Liu, 2016; He \& Ho, 2017; Liu et al., 2016; Sleegers et al., 2014; Somprach et al., 2016; Thoonen et al., 2012; Tran et al., 2018;). The most recent studies of school practices emphasize that in-service workshops and training courses and degree upgrading programmes represent a narrow vision and ineffective forms of TPD (Borko, 2004; Denton \& Hasbrouck, 2009) because those forms are inadequate to address the complexity of educational problems and issues in classroom contexts (He \& Ho, 2017). Instead, researchers have argued that significant TPD should be carried out in the context of job-embedded, collaborative, and school-based activities (He \& Ho, 2017; Kwakman, 2003; Little, 2012; Opfer \& Pedder, 2011; Timperley, 2011; Tran et al., 2018; Webster-Wright, 2009). This social aspect of TPD (Rosenholtz, 1989) raises the importance of reshaping typical norms in the school from privacy, individualism, and tradition to collegiality, collaboration, empowerment and experimentation (Barth, 1990; Clement \& Vandenberghe, 2001; Denton \& Hasbrouck, 2009; Gumus, Bulut, \& Bellibas, 2013; Heck \& Hallinger, 2014; Leithwood \& Louis, 2011; Saphier, King, \& D’Auria, 2006; Thoonen et al., 2012).

These conclusions confirm the vital roles of principals in providing favorable conditions for TPD in schools (Little, 2012; Opfer \& Pedder, 2011; Robinson et al., 2008; Timperley, 2011). Some leadership practices are relational supporting the development of norms promoting TPD (Barth, 1990; Geijsel et al., 2009; Qian \& Walker, 2013; Saphier, King, \& D’Auria, 2006; Sleegers et al., 2014). Others are instrumental to develop systems, conditions 
and processes to provide tangible support for TPD such as collaboration, teacher empowerment, instructional supervision and various motivational strategies (Hallinger, Lee, \& Ko, 2014; Leithwood, 1992; Li, Hallinger, \& Ko, 2016; Liu \& Hallinger, 2017; Qian et al., 2017; Somprach et al., 2016; Thoonen et al., 2012). Those studies have proved these things to be evident in schools in East Asian countries where hierarchy is still available and teachers feel typically more reluctant to move out of their formally assigned responsibilities (Hallinger, Lee, \& Ko, 2014; Liu \& Hallinger, 2017; Qian \& Walker, 2013; Qian et al., 2017; Somprach et al., 2016; Tran et al., 2018; Wang, 2016).

\section{The study}

The qualitative, multi-site case study design was used for this study as we emphasized on understanding through looking closely at people's words, actions and records (Denzin \& Lincoln, 2017; Maykut \& Morehouse, 1994). In the following sub-sections, we describe the processes of site selection, data collection and data analysis.

\section{Sample selection}

This research took place in Hong Lam (pseudonym) Province in the center of Vietnam. Purposeful sampling was utilized in this study to select 'information-rich cases whose study will illuminate the questions under study' (Patton, 2015, p. 169). Four schools from four educational levels in different geographical locations in Hong Lam province were considered to gain high achievements by Hong Lam Provincial Department of Education and Training. Their characteristics were as follows:

- School A: This primary school has 600 students in 15 classes from grades $1-5$ in the city. Principal Mr. Hoang (pseudonym) leads 23 staff including a deputy principal. The School has been recognized for excellence in academic and moral achievements at the provincial level. Eighteen teachers hold three-year and four-year bachelor's degrees. The Principal has 15 years of experience as a principal including twelve years at this school. Before being appointed to this post, he had been a teacher for three years and deputy-principal for seven years.

- School B: This lower-secondary school located in a rural area serving 950 students in grades 6-9. It has been recognized for excellence in academic achievement. There are 52 staff members including the principal and deputy principal. The principal, Ms. Le (pseudonym), has 10 years of experience as a principal. Thirty of the teaching staff have three-year or four year training degrees.

- School C: This high school for gifted pupils (grades 10-12) has 600 pupils from all parts of the province. Approximately 100 percent of the 12th grade pupils pass the university entrance examination every year to get admission to different universities in Vietnam. There are around 50 staff members including the principal, Mr. Nguyen (pseudonym), and deputy-principals. There are 40 teachers of whom one holds a $\mathrm{PhD}$ degree, seven hold M.A degrees, the rest have four-year training diplomas (bachelors' degrees).

- School D: A College of Vocational Training serving about 1,800 students in five departments. The College is led by a rector, Mr. Cao (pseudonym) and two deputy 
rectors. There are 120 teaching staff. According to the documents, the College has received many rewards from the provincial and MOET levels.

\section{Data collection}

The research data came from semi-structured interviews with the four principals, openended questionnaires from teachers, direct observation of professional development activities and related policy documents (Patton, 2015). Semi-structured interviews (Patton, 2015) were conducted with each of the four principals (See Appendix A). More specifically, each principal was interviewed for about 90 minutes in an office or staff room. These interviews aimed at gaining information about the principals' perspectives and their leadership practices, their roles and support as well as and teachers' professional learning activities in their schools. All the interviews were audio-recorded and later transcribed in Vietnamese. Only data extracts used as quotes in this paper were translated into English by an experienced lecturer in English and checked by the research team.In addition to the interviews with principals, teachers' perspectives were collected from an open-ended questionnaire that focused on teachers' needs and motivations as well as professional development practices used in their schools (See Appendix B). A total of 177 of 235 questionnaires distributed at teachers' meetings were returned $(75 \%$ response rate). In order to gain further details and check on what had been reported in the interviews and questionnaires, we also observed TPD activities in the four schools over a three-month period. The TPD activities included bi-monthly meeting for peer learning in three schools and monthly meeting in the college. The lead author as the investigator-in-chief of the study made notes of each meeting, which were used as a source of data. These sources of data offered multiple perspectives and enabled the use of triangulation as a means of checking the credibility of different perceptions (Creswell, 2014; Denzin \& Lincoln, 2017; Miles \& Huberman, 1994; Patton, 2015).

\section{Data analysis}

In this multi-site case study, we employed 'within-case analysis' followed by 'cross-case analysis' (Miles \& Huberman, 1994; Patton, 2015). Within-case analysis involved developing detailed write-ups for each school according to the foci of the research. Analytical procedures first involved coding data based on sources. First, we read the interview transcripts and teachers' responses to the questionnaire in order to form initial codes. Next, we related the codes to the notes of TPD activities made by the investigator-in-chief plus the policy documents. Finally, we organized the data by arranging it into a case record (or database) for each school (Patton, 2015).

In the cross-case analysis, we tried 'to build a general explanation that fit each of the individual cases, even though the cases vary in their details' (Yin, 2014, p. 112). During the process of data synthesis, we used open coding, axial coding and constant comparative method (Glaser \& Strauss, 1965; Patton, 2015). We generated categories as we searched for patterns, commonalities and contradictions among four schools (Patton, 2015). For example, the category 'collaboration' was formed by a synthesis of all the codes emerging from interview data collected from each principal, including 'sharing ideas', 'cooperating', 'providing peer feedback', 'collegiality', 'open relationship', 'peer interaction', and 'collective 
work'. Other patterns underwent a similar process. The generated categories recognized the importance of taking account of both personal and contextual influences in shaping leadership practices and workplace conditions (e.g. see Belchetz \& Leithwood, 2007; Clarke \& O’Donoghue, 2017; Hallinger, 2016; Tran et al., 2018). For data analysis in this study, we decided to embrace findings with discussion. As such, each theme or category as one of the main findings was discussed in relation the literature. For example, the pattern 'collaboration' as one of the emergent theme in this study was discussed in relation to the established literature on collaboration for TPD. By this way, we could achieve the aim as to whether TPD practices in the previous studies on principal leadership were relevant to the Vietnamese context. More importantly, grounded in Bajunid's (1996) advocacy for cultural dimensions in principal leadership, this way of data analysis helps to foreground the cultural and social aspects of the Vietnamese context.

\section{Results and discussion}

This study data confirmed the use of both external and school-based TPD activities. External activities included degree upgrading courses offered by the MOET and universities, seminars, summer workshops, short courses, and district/provincial/national good teacher title competitions. School-based activities included class observations with feedback, observations of other teachers, weekly faculty meetings, mentoring, coaching, and self-study.

Cross-school analysis of TPD activities revealed that the four schools relied mainly on 'external activities'. However, the teachers generally found these external learning activities less directly relevant, of limited use, costly, and time-consuming. In contrast, inschool learning opportunities were generally perceived as more relevant, useful, and related to perceived needs of the teachers.

These data strongly supported the proposition that workplace conditions played a critical role in promoting the extent and nature of teacher participation in TPD activities (e.g. Clement \& Vandenberghe, 2001; Hallinger \& Liu, 2016; Rosenholtz, 1989; Sleegers et al., 2014). Data analysis yielded four workplace conditions to support TPD, created by the principals, including collaboration, teacher empowerment, supervision and evaluation and teachers' motivational strategies.

In this study we examined practices used by four Vietnamese principals to support the professional learning of teachers. Although our perspective on leadership and teacher learning was initially shaped by Western literature, the use of a qualitative research methodology allowed for an exploratory rather than a confirmatory approach to the literature. Thus, we inductively identified and described leadership practices within four broad leadership strategies. Our cross-school synthesis paid particular attention to how these practices reflected the educational and cultural context of Vietnam. In the next section, we will briefly discuss workplace conditions, created by the principals, to support TPD, interpret the findings, mention the limitations, and highlight implications for research and practice.

\section{Collaboration}

In TPD, collaboration means that teachers work together, building and sustaining relationships with colleagues, promoting improvement in instructional capacity by 
providing feedback, fostering reflection on teaching skills and developing new teaching techniques (Denton \& Hasbrouck, 2009; Gumus et al., 2013; He \& Ho, 2017; Heck \& Hallinger, 2014). Collaboration was evident in all the four studied schools. It was clearly reflected in a number of strategies including observations, school or department-based seminars, mentoring, coaching and weekly professional meetings. The teachers were provided with opportunities to discuss with their colleagues professional issues for improvement and development in teachers' learning and teaching. Almost all the teachers said that they felt challenged by their colleagues. Teaching methods and problems were discussed frequently in meetings and seminars. Colleagues offered help in difficult situations. Staff said they could learn from one another during the meetings and seminars. Clement and Vandenberghe (2001, p. 45) argued this was effective when they said, '[C]ollegiality challenges teachers professionally because colleagues function for one another as a source of feedback, support and alternative ideas'. The teachers in these schools said they were eager to help one another to implement new learning or put new ideas into practice. This was similar to the pattern of successful teachers in Spillane's (1999) longitudinal study and in Heck and Hallinger's (2014) study.

Teachers' professional identity can also be developed through experiences of solidarity and collective work (Tonna \& Shanks, 2017), a process through which teachers are made aware of how they can contribute to the growth of each other's professionalism, as in Tonna and Shank's study. Most interactions between the principals and their teachers were dominated by the creation of learning opportunities. Collaboration and collegiality were evident in informal activities including the exchange of ideas or stories between the principal and teachers during the breaks. These stories had the character of noncommittal small talk. Many teachers and their principals discussed the weather, politics, shows on T.V, or their families. Often these stories grew to a sharing of ideas with regard to the school. These interactions are similar to those described in Heck and Hallinger's (2014), Rosenholtz's (1989) and Spillane's (1999) study. They were seen more frequently in schools D, C, B, and A. In school A, Mr. Hoang participated actively and frequently in all strategies with his teachers and teachers valued this cooperation. The teachers also appreciated the fact that they could easily discuss educational issues, especially issues related closely to the educational reform with their principal. In general, they did not find it difficult to ask for help. According to the teachers, they could ask Mr. Hoang for feedback about their pedagogical activities and their interactions with their pupils. Sometimes, Mr. Hoang commented spontaneously on teachers' work.

Mr. Nguyen from School C and Ms. Le from School B did similar things, but to a lesser extent. These two principals mainly discussed teaching methods with their teachers. This was because there were more subjects in their schools. Because of the college size, Mr. Cao did not meet all teachers as often as the other principals. He collaborated more with heads of departments. However, beside meeting with his teachers in seminars and meetings, he tried to talk with his teachers informally by going down to the department hall, meeting with them at social activities, organized by the department or the college, and playing sports with them.In general, in the four schools, collaboration created opportunities for the teachers and principal to share their personal opinions and beliefs about teaching. At the same time, it left room for teachers to work independently (self-learning, mentoring and discussions). Collaboration is linked with norms and opportunities for continuous improvement and career-long learning that is significant 
for improving instructional capacity (Denton \& Hasbrouck, 2009; Fullan, 2001; Gumus et al., 2013). All the four principals tried to encourage and promote interactions and cooperation mainly in professional development between teachers. The principals used reward and encouragement systems and regulations to supervise teachers. The literature indicates that collaboration in schools is on trusting, caring, and open relationships (Fullan, 2001, 2010; Hallinger \& Truong, 2014; Harris \& Jones, 2019; Tran et al., 2018). One the one hand, these constituents of collaboration were evident in the four schools. One the other hand, collaboration in these schools shows two characteristics reflecting the socio-political landscape of Vietnam, namely the 'right relationship' originated from Confucianism (Borton, 2000; Ozmon \& Craver, 2008; Tran et al., 2018; Truong, 2013) and 'the dominant political role of the Communist party' (Duiker, 1995; Vasavakul, 2019) In particular, age, status, experience, and even gender in the Vietnamese culture created an 'invisible' distance between the teachers and their principals and between teachers themselves. In general, collaboration for TPD as highlighted in the findings of this study manifests both the shared characteristics of the literature and the cultural dimensions of leadership in Vietnamese education.

\section{Teacher empowerment}

Overall, the teachers were empowered to some extent in the four schools. Teacher empowerment was evident in strategies such as seminars, weekly professional meetings, mentoring, peer coaching, and self-learning. Teachers were occasionally provided with an opportunity to be involved in decision-making and leadership roles. According to Melenyzer (1990, cited in Blasé \& Blasé, 1994) when teachers assume responsibility for an involvement in the decision-making process, true empowerment leads to increased professionalism.

Teachers in school D had more chance to take a leadership role in their professional development than their counterparts in the other three schools. For example, teachers could state their opinions on the topic selection process for seminars at the college level. They were free to choose materials for their students. They played a leadership role when organizing seminars at the department level, in mentoring and in coaching. Mr. Cao stated,

In my views, we created general policies. Teachers, based on those, take an active and creative role in generating new ideas and good ways to implement them. Sharing good ideas among teachers and reflection on their expertise are encouraged and appreciated" (DDI).

Teachers of this college could also choose the areas for self-learning they thought they needed to improve on. To a lesser extent, the teachers of the other schools experienced similar opportunities. They could take active roles in providing guidance and support to novice teachers as well as others. However, the principals were close to them and they participated in almost all areas of TPD. Thus, opportunities for empowerment for teachers were limited.Thus, Vietnamese teachers generally experienced some kind and extent of shared leadership and autonomy in their learning in the four schools. It may not have been as much autonomy, self-responsibility, and self-direction as their counterparts in Western schools might expect. Rather, teacher empowerment in the four schools focuses less on individual rights, discretion, and freedom and more on the commitments, 
obligations and duties that teachers feel toward each other, their students and the school. Based on these characteristics, we argue that teacher empowerment in these Vietnamese schools is also affected by the hierarchical structure (Borton, 2000; Hallinger \& Truong, 2016; Tran et al., 2018; Vasavakul, 2019). Again, teacher empowerment has its own cultural dimensions in response to the culture and history of Vietnam.

\section{Supervision and evaluation}

Supervision and evaluation of teachers' professional growth were evident in all schools. The management board, mainly the principal, was in charge of this task. It was considered an integral part of teachers' professional development. The role of principals in the promotion of effective professional development is reinforced by Hallinger and Liu (2016) when they suggest that instructional supervision, often provided by the principal, helps teachers improve their instructional performance, motivate their professional development and carry out their curricular development as well.

Evaluation of teachers was frequently carried out in all four schools. At the end of a semester and an academic year, teachers were assessed. Assessment was based on similar procedures and criteria in each of the schools. Teachers were assessed in terms of 'duc' and 'tai' (Doan, 2005; Mau, 1998; Hamano, 2008; Nguyen, 2002). Teachers' 'duc' often included: their patriotism, socialism and beliefs in the leadership of the Party and government, their obedience toward laws, and regulations issued by the State and MOET, their enthusiastic participation in social activities organized by the school, their collaboration in work, their behaviors toward other colleagues and their students, and the respect and prestige gained from other staff and students. Teachers' 'tai' consisted of assessed observed lessons, results of scientific studies, writings for the Bulletin of Science and presentations, and contributions to seminars. Based on such criteria, teachers wrote their own self-evaluation reports and graded themselves as A (good), B (credit), C (pass), or $\mathrm{D}$ (not completing the assigned tasks). Then, in department meetings (in schools $\mathrm{B}, \mathrm{C}$, and D) and the whole staff meeting (school A), teachers took turns to present their own reports to get feedback from their colleagues and the principal (in schools A, B, C) or heads of departments (in school D). At these meetings, constructive criticism was encouraged by all the principals. At the end of the meeting, teachers were graded by other teachers anonymously. In school D, after that meeting, lists of teachers' grades were sent to the College's Education Council for final assessment and approval.

The principals and most teachers in the four schools considered this kind of evaluation necessary and effective for recognition of their achievements and improvement. Simultaneously, this provided teachers with a chance to look back at their strengths and weaknesses and the opportunity to develop their sense of responsibility. These seemed to be similar to Little's (2012) views when (s)he suggests that evaluation is necessary for teachers' continued professional development and that good and thorough self-evaluation should include seeking the perceptions of other knowledgeable colleagues. Other authors also noted the significance and positive effects of evaluation on teachers' enhancement and development (See, for example, Little, 2012; Somprach et al., 2016).In-class supervision, as termed by Glanz and Neville (1997), to assess in-service activities was evident in the four schools. It included observations, following discussions, and assessment of teachers' lessons during the academic year, especially on special 
occasions. What some teachers had learnt from workshops and seminars was shared with other teachers. Then, the new learning was applied to classes. Observations and discussions were encouraged. This cycle was considered by principals and teachers as crucial to the success of in-service training workshops and improvement of teachers. Follow-up activities depended on observations in the school. Ms. Le and especially Mr. Hoang frequently took part in observations and discussions. Mr. Nguyen had some involvement and Mr. Cao rarely did. Follow-up activities were carried out more frequently in schools $\mathrm{A}$ and $\mathrm{B}$ where the principals were more involved. According to Botello and Glasman (1999), where there are more follow-up activities, there is more likelihood of successful in-service training courses and workshops.

In conclusion, supervision in all the four schools appeared to focus less on instructions and more on assessment. As such, this way of supervision is not similar to models of effective supervision in other education systems, especially ones of Western countries. In the schools as research sites of the current research, supervision supportted teachers in adapting, adopting, and refining the instructional practices they were trying to implement in their classrooms. The primary purpose of supervision was illustrated in Mr. Cao's views:

We supervise for good reasons. We want schools to be better, teachers to grow, and students to have academically and developmentally sound learning experiences; and we believe that supervision serves these and other worthy ends. But all the benefits that we seek can be obtained more easily and in enhanced ways in the natural course of events as teachers and students learn together in the school." (DDI).

According to Hairon and Dimmock (2012), the type of instructional supervision that is most likely to produce productive professional development is that of collaboration. The supervision in the four schools is tailored for the education context in Vietnam. As a result of this, supervision in these schools is not like the one employed in Western schools.

\section{Motivational strategies}

The teachers in the four schools were motivated to continuously update their knowledge and professionalism. The motivation system in these schools often included policies, regulations, rewards, recognition, and punishment. It appeared that the four principals used different motivational strategies to promote teachers' professional development.

In order to apply suitable motivational strategies to individual teachers with different needs, the principals were reported to have an understanding of their teachers. Generally, the principals understood almost all of their teachers' family situations. Family situations in Vietnam appear to have a great impact upon teaching and learning. For example, Vietnamese female teachers have to be involved in work and family as well. Because of an influence of Confucianism, they have to take responsibility for household chores. Thus, they have less time for self-learning than their male counterparts. The principals acknowledged the differences in teachers' needs, age, gender, and financial conditions when employing strategies of professional development. This was reflected in compulsory and optional strategies applied in schools. For example, observations, scientific studies, and self-learning were compulsory and degree upgrading was optional. All 
teachers valued these understandings. There were no indications of unfair considerations or teachers' dissatisfied attitudes toward their principal's acknowledgments of different needs in the interview or questionnaires. School reports and my observations confirmed these. These principals' actions seem to be consistent with what $\mathrm{He}$ and Ho (2017) suggests. They say that the use of suitable motivational strategies based on individuals' needs and work characteristics is very important to stimulate teachers to improve (Kwakman, 2003). Darling-Hammond and Richardson (2009) and Fullan (2010) also argue that teachers' needs must be taken into consideration when employing teachers' professional development strategies.

Policies of rewards and punishment were used to implement and promote TPD in all four schools. Teachers with high achievements or good progress including successful completion of degree upgrading, attaining 'good teacher' titles, good grades for scientific studies, and so on, were recognized, appreciated, and awarded with money. These teachers were publicly appreciated and praised. According to Mr. Hoang, when a teacher completes a 'degree upgrading' course, at the staff's meeting, that graduate is awarded with 'a small gift as a kind of reward and recognition of his/her endeavor'. The value of such an incentive was explained: 'Although the reward is small because of the difficulty in finance, it is great encouragement for that teacher in front of his/her colleagues' (ALI). Teachers with 'good teacher' titles were recognized and awarded amounts of money in schools B, C, and D. Mr. Cao said that in his college, teachers with high achievements and grades were received more money than others on some occasions such as Vietnamese Teachers' Day and Lunar Year (Tet) Holidays. Teachers in schools A, B, and C were also awarded with money if their students passed the 'good student' competition at DETS or PETS levels. Thus, it is a fact that teachers normally wanted to teach the more able students. However, the principals tried to assign teachers to teach different classes. Teachers in the four schools with their scientific studies recognized at DETS or PETS levels were awarded with money as well. The higher the level was the more money and respect the teachers gained. These kinds of rewards seemed to make teachers competitive and they are not always encouraged in Western schools. London (2011) argues from the left that the sense of competitiveness partly prevents teachers from collaborating with their colleagues. Although the principals and teachers did not mention the sense of competitiveness in the interviews and questionnaires (they might not have realized or they would not have wanted to say about), we saw evidence of the sense of competitiveness amongst teachers in the four schools.

One kind of motivation that reflects cultural dimensions of Vietnamese style of leadership is 'reward of spirit'. This term was repeated in the principals' interviews and teachers' questionnaires. They said that the reward of a Vietnamese teacher can be good and wellbehaved students and that he/she is loved and respected by their colleagues and students' parents. This is very important for teachers. Thus, the principals said that they often reminded their teachers about the honor of the teaching profession in the Vietnamese society. Most teachers wrote that their professional development was mainly important to them because they could help improve their 'dear students' learning and achievements. This could result from an influence of Confucianism that teachers should be good and hold high respect in society (Hallinger \& Truong, 2014; Huynh, 2002; Ozmon \& Craver, 2008; Tran et al., 2018; Truong \& Hallinger, 2017).Teachers in the four schools said their principals placed high expectations on them to improve their learning and teaching. 
Mr. Hoang noted the 'school A pride' for teachers to strive more in learning and teaching. However, the principals realized that their teachers' salaries were not sufficient for their living, therefore their teachers could not put as much effort into teaching and learning as they might desire. Thus, rewards from the schools were often money. All four schools said that they lacked the finance for better encouragement and worthy rewards for their high achieving teachers. All four principals, living and working in a hierarchical society, were seen to use ' $\mathrm{X}$ ' theory in some cases to motivate their teachers.

According to Borton (2000), Nguyen (2016), Tran et al. (2018), and Truong (2013), in Vietnamese culture, achievement goals are often described as being for the benefit of the group (e.g. family or organization or state). Mai (2007) also suggests that collective cultures emphasize achievement more in terms of benefits to the in-group. According to him/her, people in these cultures are often motivated to study because of a stronger emphasis placed by their family, organization, and society on education as a means to achieve wealth and status. Moreover, the sense of 'losing face' could motivate people to learn. This practice of motivating teachers is traced back to an established norm in Vietnamese society. That is, 'a small food given formally to a person in front of the whole villagers is considered more precious than a basket of food given informally to him/her in the house' still holds true in organizations including schools. The four principals seemed to understand these cultural aspects embedded in their teachers as Vietnamese in order to motivate their teachers more effectively. For example, the teachers were often praised and rewarded publicly.

\section{Limitations of the study}

Like other case study research, this study involved a limited and specific population of participants. Therefore, the findings of this research cannot be generalized to the larger population of Vietnamese schools and educators (Yin, 2014). In addition, it is possible that the information and perspectives shared with the researchers conveyed 'overly positive' assessments of modal practices in the schools. While this is a commonly noted threat to validity in qualitative research (Burns, 2000; Creswell, 2014), features of Vietnamese culture and Vietnamese context could have exaggerated this tendency in our study. More specifically, Vietnamese people behave in accordance with the norm of 'good things are revealed and bad things should be covered up (tốt khoe xấu che). Although our use of data triangulation, especially observations, tried to improve credibility and validity, we acknowledge this as a limitation of our study.

As in the findings of the current study, the level of schools played a role in the leadership practices used by the principals. In particular, the principals from primary and lower-secondary schools were more involved in TPD than the principals from upper secondary and vocational training schools. We did not discuss this aspect in detail due to the limitations of the study. As such, the role of school level in principal leadership should be a useful topic for future research on educational leadership in the sociocultural context of Vietnam.

\section{Conclusion}

The principal leadership strategies identified aimed at supporting TPD identified in this study echo themes that have been well discussed in Western nations. Nonetheless, it was 
obvious that the implementation of these strategies in typical schools in Vietnam had a different feature which reflected the influence of the political, cultural, and socioeconomic context of Vietnam. The findings offer support to the ideas of Belchetz and Leithwood (2007), Harris and Jones (2019) or Hallinger and Heck (2010) that a similar successful leadership practices are found in different countries. At the same time, they reinforce Bajunid's (1996) idea that these similar practices (e.g. empowerment, collaboration, supervision) may take on different patterns in different countries. This was evident in the current study and needs more qualitative studies that elaborate on and connect leadership and TPD practices to the contextual features of different countries (Belchetz \& Leithwood, 2007; Clarke \& O'Donoghue, 2017).

In this research article, we have periodically compared our findings in the four schools in Hong Lam province, Vietnam to the studies of leadership and TPD conducted in Western countries. Indeed, as noted above, we concluded that differences in these practices could be traced to differences in the educational and socio-cultural context. However, it should be noted that in recent years an increasingly rich literature centering on this topic has emerged in East Asia with the studies from Hong Kong (Hallinger \& Liu, 2016; He \& Ho, 2017), China (Hallinger \& Liu, 2016; Qian \& Walker, 2013; Qian et al., 2016), Thailand (Hallinger et al., 2017; Somprach et al., 2016), and Singapore (Hairon \& Dimmock, 2012). Future studies should assume the challenge of examining commonalities and differences in these processes within East Asian societies. This will not only offer policymakers, educational authorities and practitioners in the region insights into further development directions, but also contribute toward building a more diverse global literature in educational leadership and management as a whole (Bajunid, 1996; Clarke \& O’Donoghue, 2017).

We focused explicitly on describing TPD practices and interpreting them through the political-cultural-social lens of the Vietnamese context. Nonetheless, if we compare Vietnam with findings reported from China and Singapore, the schools in Hong Lam province, Vietnam in particular and perhaps in Vietnam in general, lag these other East Asian countries on both the scope and quality of leadership and TPD. This would suggest that there remains a gap for further studies in the field in Vietnam.

\section{Disclosure statement}

No potential conflict of interest was reported by the authors.

\section{Funding}

This research was funded by Vietnam National Foundation for Science and Technology Development (NAFOSTED) under the grant number 503.99-2018.301.

\section{Notes on contributors}

Hai-Ngoc Tran, got an MA from Otago University, New Zealand, and is currently doing his PhD at Vietnam National Institute of Educational Sciences, Hanoi, Vietnam. He is a senior lecturer at Department of Foreign Languages, Ha Tinh University, Vietnam. His research interests include 
language pedagogy, language acquisition and testing, teacher education, educational management and leadership, and teacher professional development.

Duc-Chinh Nguyen, got his PhD from Monash University, Australia, and currently working as a lecturer at Department of English, Da Nang College of Foreign Languages, Vietnam. His research intersts include language pedagogy, language acquisition, teacher education, teacher leadership, teacher professional development.

Gia-Viet Nguyen got his PhD from Waikato University, New Zealand. He is currently a senior lecturer at Department of Foreign Languages, Ha Tinh University and a principal of Albert Einstein School, Vietnam. His research intersts include language pedagogy, language acquisition, teacher education, teacher professional development.

Thi-Nga Ho got her PhD from Vietnam National Institute of Educational Sciences, Hanoi, Vietnam. She is currently Head of Department of External Relations and Communication, Ha Tinh University, Vietnam. Her research interests include language pedagogy, language acquisition, teacher education, educational management and leadership and teacher professional development.

Quynh-Tho Thi Bui got her PhD from Academy of Finance in Hanoi, Vietnam. She is currently Head of Scientific Research Management, Ha Tinh University, Vietnam. Her research interests include econoics, business administration, finance, education and teacher professional development.

Ngoc-Ha Hoang got his PhD from College of Economics of Hanoi National University, Vietnam. He is currently Head of Academic Affairs, Ha Tinh University, Vietnam. His research interests include econoics, business administration, finance, education and teacher professional development.

\section{ORCID}

Hai-Ngoc Tran (D) http://orcid.org/0000-0003-3326-1365

Duc-Chinh Nguyen (D) http://orcid.org/0000-0002-7015-2064

\section{References}

Bajunid, I. A. (1996). Preliminary explorations of indigenous perspectives of educational management: The evolving Malaysian experience. Journal of Educational Administration, 34(5), 50-73. doi:10.1108/09578239610148278

Barth, R. S. (1990). Improving schools from within. San Francisco: Jossey-Bass.

Belchetz, D., \& Leithwood, K. (2007). Successful leadership: Does context matter and if so, how? In C. Day \& K. Leithwood (Eds.), Successful principal leadership in times of change: An international perspective (pp. 11-137). Dordrecht, The Netherlands: Springer.

Blasé, J., \& Blasé, J. (1994). Empowering teachers: What successful principals do. Thousand Oaks, CA: Corwin.

Borko, H. (2004). Professional development and teacher learning: Mapping the terrain. Educational Researcher, 33(8), 3-15.

Borton, L. (2000). Working in a Vietnamese voice. Academy of Management Executive, 14(4), 20-29.

Botello, M., \& Glasman, N. S. (1999). Dimensions of teacher in-service training for school improvement. The International Journal of Educational Management, 13(1), 14-25.

Burns, R. B. (2000). Introduction to research methods (4th ed.). New South Wales: Longman.

Clarke, S., \& O’Donoghue, T. (2017). Educational leadership and context: A rendering of an inseparable relationship. British Journal of Educational Studies, 65(2), 167-182.

Clement, M., \& Vandenberghe, R. (2001). How school leaders can promote teachers' professional development. School Leadership and Management, 21(1), 43-57. 
Cravens, X. C. (2008). The cross-cultural fit of the learning-centered leadership framework and assessment for Chinese principals.Unpublished doctoral dissertation, Vanderbilt University, Nashville, TN.

Creswell, W. J. (2014). Research design: Qualitative, quantitative and mixed methods approaches (4th ed.). Thousand Oaks, CA: Sage.

Dalton, R. J., Hac, P. M., Nghi, P. M., \& Ong, N. N. T. (2001). Social relations and social capital in Vietnam: The 2001 world values survey. Retrieved from http://www.worldvaluessurvey.org/ Upload/5_viet.pdf

Darling-Hammond, L., \& Richardson, N. (2009). Teacher learning: What matters? Educational Leadership, 66(5), 46-53.

Denton, C. A., \& Hasbrouck, J. (2009). A description of instructional coaching and its relationship to consultation. Journal of Educational and Psychological Consultation, 19, 150-175.

Denzin, N. K., \& Lincoln, Y. S. (2017). Handbook of qualitative research (5th ed.). London: Sage.

Doan, D. H. (2005). Moral education or political education in the Vietnamese educational system. Journal of Moral Education, 34(3), 451-463.

Duc, T. K. (2008). Vietnamese schooling in transition: Industrialization and modernization. Journal of International Cooperation in Education, 11(1), 85-96.

Duggan, S. (2001). Educational reform in Vietnam: A process of change or continuity? Comparative Education, 37(2), 193-212.

Duiker, J. W. (1995). Vietnam: Revolution in transition. San Francisco: Westview Press.

Fullan, M. (2001). Leading in a culture of change. San Francisco: Jossey Bass.

Fullan, M. (2010). Positive pressure. In A. Hargreaves, A. Lieberman, M. Fullan, \& D. Hopkins (Eds.), Second international handbook of educational change (pp. 119-130). Dordrecht: Springer.

Geijsel, F. P., Sleegers, P. J., Stoel, R. D., \& Krüger, M. L. (2009). The effect of teacher psychological and school organizational and leadership factors on teachers' professional learning in Dutch schools. The Elementary School Journal, 109(4), 406-427.

Glanz, J., \& Neville, R. F. (Eds.). (1997). Educational supervision: Perspectives, issues, and controversies. Norwood, MA: Christopher-Gordon.

Glaser, B. G., \& Strauss, A. L. (1965). The constant comparative method of qualitative analysis. Social Problems, 12(4), 436-445.

Gumus, S., Bulut, O., \& Bellibas, M. S. (2013). The relationship between principal leadership and teacher collaboration in Turkish primary schools: A multilevel analysis. Education Research and Perspectives, 40(1), 1-29.

Hac, P. M. (1998). Renovation of Vietnam's education for the cause of industrialization and modernization of the country. Ha Noi: Education Publishing House.

Hairon, S., \& Dimmock, C. (2012). Singapore schools and professional learning communities: Teacher professional development and school leadership in an Asian hierarchical system. Educational Review, 64(4), 405-424.

Hallinger, P. (2016). Bringing context out of the shadows of leadership. Educational Management Administration \& Leadership, 1-20. doi:10.1177/1741143216670652

Hallinger, P., \& Heck, R. (2010). Collaborative leadership and school improvement: Understanding the impact on school capacity and student learning. School Leadership and Management, 30(2), 95-110. doi:10.1080/13632431003663214

Hallinger, P., Lee, M. S., \& Ko, J. (2014). Exploring the impact of school principals on teacher professional communities in Hong Kong. Leadership and Policy in Schools, 13(3), 229-259.

Hallinger, P., \& Liu, S. (2016). Leadership and teacher learning in urban and rural schools in China: Meeting the dual challenges of equity and effectiveness. International Journal of Educational Development., 51, 163-173.

Hallinger, P., Piyaman, P., \& Viseshsiri, P. (2017). Assessing the effects of learning-centered leadership on teacher professional learning in Thailand. Teaching and Teacher Education, 67, 464-476.

Hallinger, P., \& Truong, D. T. (2014). Exploring the contours of context and leadership effectiveness in Vietnam. Leading and Managing, 20(2), 43-59. 
Hallinger, P., \& Truong, D. T. (2016). Above must be above, and below must be below: Enactment of relational school leadership in Vietnam. Asia Pacific Education Review, 17(4), 677-690.

Hamano, T. (2008). Educational reform and teacher education in Vietnam. Journal of Education for Teaching, 34(4), 397-410.

Harris, A., \& Jones, M. (2019). Leading professional learning with impact. School Leadership and Management, 39(1), 1-4.

Harris, A., Jones, M., \& Huffman, J. (2017). Teachers leading educational reform: The power and potential of professional learning communities. London: Routledge.

He, P., \& Ho, D. (2017). Leadership for school-based teacher professional development: The experience of a Chinese pre-school. International Journal of Leadership in Education, 20(6), 717-732.

Heck, H. R., \& Hallinger, P. (2014). Modeling the longitudinal effects of school leadership on teaching and learning. Journal of Educational Administration, 52(5), 653-681.

Hoang, D. T. (2002, November). Thinking about Vietnamese teachers' dignity in the educational cause of today. The Educational Review, 44, 2-4.

Huynh, D. T. (2002). Vietnamese culture: Teacher-student relationship. Retrieved from http:// www.geocities.com/SoHo/Den/5908/values/html/

Jamieson, N. L. (1993). Understanding Vietnam. Berkeley, CA: University of California Press.

Joyce, B. R. (1988). Training research and preservice teacher education: A reconsideration. Journal of Teacher Education, 39(5), 32-36.

Kwakman, K. (2003). Factors affecting teachers' participation in professional learning activities. Teaching and Teacher Education, 19(2), 149-170.

Lai, C., Li, Z., \& Gong, Y. (2016). Teacher agency and professional learning in cross-cultural teaching contexts: Accounts of Chinese teachers from international schools in Hong Kong. Teaching and Teacher Education, 54, 12-21.

Lan, P. T. P. (2002). Mapping values in educational management and leadership in Vietnam: The impact of culture (Unpublished master's dissertation). Dunedin College of Education, New Zealand.

Leithwood, K. A. (1992). The principal's role in teacher development. Teacher Development and Educational Change., 2(5), 86-103.

Leithwood, K. A., \& Louis, K. S. (2011). Linking leadership to student learning. New York: John Wiley \& Sons.

Li, L., Hallinger, P., \& Ko, J. (2016). Modeling the effects of principal leadership and school capacity on teacher professional learning in Hong Kong primary schools. International Journal of Educational Management, 30(1), 76-100.

Lieberman, A., \& Pointer Mace, D. H. (2008). Teacher learning: The key to educational reform. Journal of Teacher Education, 59(3), 226-234.

Little, J. W. (2012). Professional community and professional development in the learningcentered school. In M. Kooy \& K. van Veen (Eds.), Teacher learning that matters: International perspectives (pp. 22-46). London: Routledge.

Liu, S., \& Hallinger, P. (2017). Leading teacher learning in China: A mixed methods study. In K. Leithwood, J. Sun \& K. Pollock (Eds.), How school leadership influences student learning: The four paths (pp. 279-303). Dordrecht, The Netherlands: Springer.

Liu, S., Hallinger, P., \& Feng, D. (2016). Supporting the professional learning of teachers in China: Does leadership make a difference?. Teaching and Teacher Education, 59, 79-91.

London, J. D. (2010). Contemporary Vietnam's education system: Historical roots, current trends. In Education in Vietnam (pp. 1-56). Singapore: Institute of Southeast Asian Studies.

Mai, N. (2007). Managing further professional training for primary school teachers in Phu Giao district, Binh Duong province (Unpublished master degree thesis). Ho Chi Minh City University of Pedagogy, Ho Chi Minh City, Vietnam. (in Vietnamese)

Mau, P. T. (1998). Present situation, needs and solutions for developing teachers based on Vietnam's strategic plan for education and training. In Institute of Educational Research and Development (Ed.), Vietnamese education in the 21st century: Contexts, tendency and developmental motivations (pp. 131-149). Ha Noi: Education Publishing House. (in Vietnamese). 
Maykut, P., \& Morehouse, R. (1994). Beginning qualitative research: A philosophic and practical guide. London, UK: The Falmer Press.

Miles, M. B., \& Huberman, M. A. (1994). Qualitative data analysis: A sourcebook of new methods (2nd ed.). Newbury Park: Sage.

Ministry of Education and Training (MOET). (2012). Vietnamese education and training development strategy plan for 2015-2020 for the cause of industrialization and modernization of Vietnam. Ha Noi: Education Publishing House.

Newmann, M. F., King, B., \& Youngs, P. (2000). Professional development that addresses school capacity: A lesson from urban elementary schools. American Journal of Education, 108(4), 259299.

Nguyen, C. T. (2002). On the good teacher. In C. T. Nguyen (Ed.), The corpus of discussions on education (pp. 390-398). Ha Noi: Labour Publishing House.

Nguyen, D. (2003). Fostering quality teaching and school managers thru professional growth plans to keep pace with the policies on educational curriculum innovation at high schools in Tay Ninh province. Education Review, 46, 39-40. (in Vietnamese).

Nguyen, K. V. (2013). Vietnamese buddhism at Ly-Tran dynasty history - Entering capacity and social roles. In A. Tatsuru. \& E. Sakamoto (Eds.), The role of Buddhism in social work: Vietnam and Japan (pp. 5-19). Japan: Asia and Pacific Association for Social Work Education.

Nguyen, T. N. Q. (2016). The Vietnamese values system: A blend of oriental, western and socialist values. International Education Studies, 9(12), 32-40.

Opfer, V. D., \& Pedder, D. (2011). Conceptualizing teacher professional learning. Review of Educational Research, 81(3), 376-407.

Ozmon, H. A., \& Craver, S. M. (2008). Philosophical foundations of education (8th ed.). Upper Saddle River, NJ: Prentice-Hall.

Patton, M. Q. (2015). Qualitative research and evaluation methods (4th ed.). Newbury Park, CA: Sage.

Poekert, P. E. (2012). Teacher leadership and professional development: Examining links between two concepts central to school improvement. Professional Development in Education, 38, 169-188.

Qian, H., \& Walker, A. D. (2013). How principals promote and understand teacher development under curriculum reform in China. Asia-Pacific Journal of Teacher Education, 41(3), 304-315.

Qian, H., Walker, A. D., \& Yang, X. (2016). Building and leading a learning culture among teachers: A case study of a Shanghai primary school. Educational Management Administration \& Leadership, 45(1), 101-122.

Qian, H., Walker, A. D., \& Yang, X. (2017). Building and leading a learning culture among teachers: A case study of a Shanghai primary school. Educational Management Administration \& Leadership, 45(1), 101-122.

Robinson, V. M., Lloyd, C. A., \& Rowe, K. J. (2008). The impact of leadership on student outcomes: An analysis of the differential effects of leadership types. Educational Administration Quarterly, 44(5), 635-674.

Rosenholtz, S. J. (1989). Teachers' workplace: The social organization of schools. New York: Longman.

Saphier, J., King, M., \& D’Auria, J. (2006). Three strands form strong school leadership. Journal of Staff Development, 27(2), 51-57.

Sleegers, P., Thoonen, E., Oort, F., \& Peetsma, T. (2014). Changing classroom practices: The role of school-wide capacity for sustainable improvement. Journal of Educational Administration, 52 (5), 617-652.

Somprach, K., Tang, K. N., \& Popoonsak, P. (2016). The relationship between school leadership and professional learning communities in Thai basic education schools. Educational Research for Policy and Practice, 2(16), 157-175.

Spillane, J. P. (1999). External reform initiatives and teachers' efforts to reconstruct their practice: The mediating role of teachers' zones of enactment. Journal of Curriculum Studies, 31(3), 143-175. 
The Communist Party of Vietnam (CPV). (2012). The education development strategic plan for 2001-2010. Retrieved from http://vietnamlawmagazine.vn/decision-no-711-qd-ttg-of-june-132012-approving-the-2011-2020-education-development-strategy-4704.html

Thoonen, E. E., Sleegers, P. J., Oort, F. J., \& Peetsma, T. T. (2012). Building school-wide capacity for improvement: The role of leadership, school organizational conditions, and teacher factors. School Effectiveness and School Improvement, 23(4), 441-460.

Timperley, H. (2011). Realizing the power of professional learning. London: McGraw-Hill Education.

Tonna, M. A., \& Shanks, R. K. (2017). The importance of environment for teacher professional learning in Malta and Scotland. European Journal of Teacher Education, 40(1), 91-109.

Tran, H. N., Hallinger, P., \& Truong, D. T. (2018). The heart of school improvement: A multi-site case study of leadership for teacher learning in Vietnam. School Leadership and Management, 38 (1), 80-101.

Truong, D. T. (2013). Confucian values and school leadership in Vietnam (Unpublished Ph.D. dissertation). Victoria University of Wellington, Wellington, New Zealand.

Truong, D. T., Hallinger, P., \& Sanga, K. (2016). Confucian values and school leadership in Vietnam: Exploring the impact of culture on principal decision-making. Educational Management Administration \& Leadership, 45(1), 77-100.

Truong, T. D., \& Hallinger, P. (2017). Exploring cultural context and effective school leadership: Conceptualizing an indigenous model of có uy school leadership in Vietnam. International Journal of Leadership in Education, 20(5), 539-561.

Vasavakul, T. (2019). Vietnam: A pathway from state socialism. Cambridge, UK: Cambridge University Press.

Vescio, V., Ross, D., \& Adams, A. (2008). A review of research on the impact of professional learning communities on teaching practice and student learning. Teaching and Teacher Education, 24, 80-91.

Wang, T. (2016). School leadership and professional learning community: Case study of two senior high schools in Northeast China. Asia Pacific Journal of Education, 36(2), 202-216.

Webster-Wright, A. (2009). Reframing professional development through understanding authentic professional learning. Review of Educational Research, 79(2), 702-739.

Yin, R. K. (2014). Case study research: Design and methods (5th ed.). Thousand Oaks, CA: Sage.

Youngs, P., \& King, M. B. (2002). Principal leadership for professional development to build school capacity. Educational Administration Quarterly, 38(5), 643-670.

\section{Appendices}

\section{Appendix A. Interview questions for the principals}

(1) Name: ................... Male $\square$ Female $\square$ Age: $\square$

(2) How long were you a teacher before taking an administrative position?

(3) How long have you been a principal?

(4) What do you think of the quality of teachers in general in Vietnam? How important is teacher quality for student achievement and outcomes of education?

(5) What do you understand by the term 'teacher professional development'?

(6) How do you perceive the importance of the professional development of teachers to achieving education reforms in Vietnam?

(7) What policies in the school support teacher involvement in professional development? Does the school have rewards, support, and punishments that are used to motivate teachers?

(8) What strategies have you used to promote the professional development of your teachers in your school? Could you give me examples and details, please.

(9) What are the advantages and disadvantages of each strategy?

(10) Which strategies have been most effect? Which have been least effective? Why? 
(11) Do these strategies work with all teachers (e.g. junior, senior)? Do you adjust your strategies for different teachers? Why? How?

(12) What successes have you observed during implementation of these strategies? What evidence do you have for this belief? Can you think of any others?

(13) What difficulties/challenges have you faced during the implementation of those strategies? Why?

(14) Are some teachers unwilling or less enthusiastic to take part in professional development? Which teachers? What do you think are their reasons? How do you manage that? Can you give some examples?

(15) How can you support your teachers through change if they are not happy or unsure about it?

(16) How do you encourage teachers to cooperate and share ideas, experiences, and expertise with their colleagues? When does this kind of sharing occur most frequently?

(17) How do your relationships with your teachers influence your ability to motivate and engage them in professional development?

(18) How do you build and sustain those relationships?

(19) What would you like to do to improve the quality of teacher professional development in your school?

\section{Appendix B. Questionnaire for teachers}

(1) MaleFemaleAgeYears teaching experienceGrade/Subject:

(2) What do you understand by the term 'teacher professional development'?

(3) What is your opinion about the quality of teaching in general? How important is it for the students' achievement and outcomes of education?

(4) What is the role of teacher professional development in educational reform in Vietnam? Is it important? If yes, why? If not, why?

(5) What strategies have you participated in to upgrade your professional knowledge? (e.g. staff meetings, seminars, self-teaching, MOET courses, workshops etc.)

(6) Which strategies do you find more useful and less useful? Why?

(7) How is teachers' professional development carried out in your school? (e.g. organization of professional development, types of activities, routine activities, special activities...)

(8) To what extent and in what ways are you involved in those strategies?

(9) What motivates you to participate in professional development? (e.g. school's require- ment, education policy, peer pressure, principal expectations, rewards, others)?

(10) In what ways does your principal motivate you to engage in professional development?

(11) More broadly, what roles does your principal play in the professional development of teachers?

(12) In what ways has s/he supported your professional learning on the job.

(13) How are your relationships with the principal and other colleagues? How would you describe the principal's relationship with the teaching staff?

(14) What kinds and additional support do you need to learn productively on the job?

(15) What benefits have you gained from your involvement in professional development?

(16) What difficulties/challenges have you encountered in professional development at work?

(17) Do you have any further comments about your experiences in professional development?

(18) What are your suggestions to improve teacher professional development within your school? 